\title{
REVEALING PROBLEMS ON TEACHING ENGLISH FOR YOUNG LEARNERS AT AL-AZHAR 55 ISLAMIC PRIMARY SCHOOL YOGYAKARTA AND HOW TO SOLVE THEM
}

\author{
Anang Widodo, Septi Riana Dewi \\ University of Technology Yogyakarta \\ mr.anangwidodo@gmail.com \\ University of Technology Yogyakarta \\ ceriadewi_84@yahoo.com
}

\begin{abstract}
The present paper aims to reveal the problems faced by teachers when teaching English for second - grade students at Al - Azhar 55 Islamic Primary School in Yogyakarta. This bilingual school is considered as a pilot project which began the program in July 2016. There are only 2 classes which are the first and second grade. However, this study involved 21 second-grade students, 2 homeroom teachers, and 1 native speaker. Qualitative method was applied in this study by combining document analysis, observation, and interview both students and the teachers. The results show some problems occurred during teaching and learning process and how the teachers overcome them. The problems were (1) students' lack of discipline during teaching and learning process (2) the variety of students' English ability, (3) difficulty in creating habit to use English as daily language, and (4) less support from parents. While, the solutions were (1) applying Class Dojo application, (2) providing the preparation class, (3) support and assistance from teachers and friends, and (4) hands - on learning.
\end{abstract}

Keywords: Bilingual school, problems, solutions, Class Dojo application

Abstrak. Penelitian ini bertujuan untuk mengungkapkan permasalahan yang dihadapi oleh para guru ketika mengajar Bahasa Inggris untuk kelas dua di SDIT Al - Azhar 55 Yogyakarta. Sekolah bilingual yang memulai programnya pada bulan Juli 2016 ini dijadikan sebagai sebuah pilot project. Oleh karena itu, di sekolah ini hanya terdapat 2 kelas saja, yaitu kelas satu dan kelas dua.Namun demikian, penelitian ini hanya melibatkan 21 orang siswa dari kelas dua, 2 orang guru kelas dua, dan 1 orang pengajar asing.Metode kualitatif digunakan dalam penelitian ini dengan mengkombinasikan beberapa cara pengumpulan data, yaitu analisis dokumen, pengamatan kelas, dan wawancara, baik dengan beberapa siswa, para guru kelas, dan pengajar asing. Hasil penelitian menunjukkan bahwa ada beberapa permasalahan yang muncul selama proses belajar mengajar dan cara yang dilakukan oleh para pengajar untuk mengatasinya. Permasalahan yang muncul antara lain adalah (1) kurangnya disiplin para siswa selama proses belajar mengajar, (2) bervariasi atau beragamnya kemampuan para siswa, (3) sulitnya menciptakan sebuah kebiasaan untuk menggunakan Bahasa Inggris sebagai bahasa keseharian, (4) dan kurangnya dukungan dari para orang tua. Sementara itu, solusi untuk mengatasi permasalahan tersebut adalah melalui (1) penggunaan aplikasi Class Dojo, (2) penyediaan kelas persiapan, (3) pemberian dukungan dan bantuan dari para guru dan teman-teman sekelas, (4) dan hands-on learning.

Kata kunci: sekolah bilingual, permasalahan, solusi, aplikasi class dojo 


\section{Introduction}

Considering as foreign language in Indonesia, English remains one of favorite languages to study. Many parents send their children to International or bilingual schools, and English courses since they are kids. Therefore, bilingual or international schools and English courses are very popular in Indonesia.The ability to speak English fluently is assumed as the key to success, thus, by providing English environment, young learners are easier to master this language because they tend to speak English every day when socializing or communicating with their friends and teachers. Sayer (2012) states that some other languages can be learned after the early socialization process and those languages are generally acquired in formal school settings. A child learns a language during socialization process and it is through this language that words are arranged in accordance with certain rules to make the individual understood and understand what's going on around(Handel, 2006, cited in Sen, 2014).In addition, it is considered that the best time to learn language is in early age (Y.Hu, 2007)

$\mathrm{Al}$ - Azhar 55 Islamic Primary School is one of several bilingual schools in Yogyakarta. Founded in 2016, this school has merely two classes which are the first and second grade. English is compulsory language used in school. Therefore, all students are required to speak English at school all time. Since not all students are able to speak English, several problems occur during teaching and learning process. This study, thus, highlights those problemsand figuresout how teachers overcome them.

Relating to the topic discussed, Strakova (2015) highlights that the challenge in teaching young learners in Slovakia lies on teachers' capability to teach young learners and lack of experiences they have. This study implemented experiment methods which involved 55 students in experiment class and 55 students in control class. However, this study more focused on reading skill.
Meanwhile, the study conducted by Copland, Garton, and Burns (2014) has highlight a number of issues in teaching English to young learners. It involved a huge number of respondents in five different primary schools in five different countries. A mixedmethods approach was used to obtain the data, including a survey, which was completed by 4,459 teachers worldwide. Besides, case studies, including observations and interviews with teachers was applied. The results show that there are challenges faced teachers when teaching English for young learners, which are (1) lack of training, (2) lack of knowledge, and (3) lack of resources, (4) the government policy, (6) class size, (7) teachers' own skills and confidence in English, and time pressures. In the previous studies, many schools were involved as research setting, while, the present study focus on one school which is considered as pilot project of bilingual school.

Stakanova\&Tolstikina(2014) argue that teaching English is better when it starts from early age because (1) it stimulates the language and overall development of children and, as a consequence, increases the value of comprehensive early childhood education and elementary education as the foundation of general education; (2) it attaches children to other cultures, thereby forming a universal consciousness; (3) it creates a favorable basis for mastering a foreign language, as well as for further language learning at later stages; and (4) it can improve general educational skills (e.g, ability to work with the book) by expanding their scope in the process of mastering a foreign language. It implies that teaching language to young learners has more benefit for them when they are growing up; besides, they can learn language effectively.

\section{Research Method}

Qualitative method is applied in this study. The data were collected by combining amongdocument analysis, observation, and interview. Documents are considered as important data in qualitative research. Creswell (2008) states that these sources (documents) 
provide valuable information in helping researchers understand central phenomena in qualitative studies. Analyzing documents is needed to get more information and data needed. Besides analyzing the document, observation was conducted to collect the first-hand data. Observation is the process of offering open-ended, firsthand information by observing people and place at a research site (Creswell, 2008) Meanwhile, interviews in qualitative study will be beneficial to obtain unique information or interpretation held by the person interviewed, collect a numerical aggregation of information from many persons, and find out about "a thing" that the researchers were unable to observe themselves (Stake, 2010). Therefore, interview reminds crucial to dig the information in depth from participants in which it cannot be revealed by document analysis and observation.

Since the students were very active during teaching and learning process, the use of video was omitted. Besides, the existence of video to record all activities during teaching and learning process would distract students. Note taking, thus, was used to get all information and data during the observation. After collecting data fromobservation, the researchers conducted some interviews with students and teachers to crosscheck all information and data from observation.

Since there are only two grades at this school, the study merely involved the second grade students since it was considered that they were able to cooperate with the researchers during the study. This study, thus, involved 21 students, 2 homeroom teachers, and 1 native speaker.

To analyze the data collected, the researchers used the model data analysis proposed by Miles and Huberman (1984: 21) They consider that there are three concurrent flow of activity in analyzing qualitative data, which are data reduction, data display, and conclusion drawing / verification.

The stage on data reduction enabled the researchers to select the useful data and information related to topic discussed which was conducted during the observation and those from document analysis and interview. These data, then, were organized based on two criteria, which are problems occurred and solutions given. The following stage was data display. In this study, narrative text was used to elaborate the data into informative explanation. Besides, the data were also interpreted in the form of table. Conclusion, drawing/ verification, thus, was the last stage of analyzing data. In this stage, the researchers drew the conclusion from the data collected to figure out the problems on teaching English for young learners at Al - Azhar 55 Islamic Primary School Yogyakarta and teachers' solutions on those problems.

\section{Result and Discussion}

\section{Result}

The findings reported in this study will be presented into two categories, which are problems faced by teachers and solutions of those problems.

\section{Problems}

To teach English at Al - Azhar 55 Islamic Primary School, teachers face some problems as follow,

a. Not all students come from bilingual kindergarten, thus, their English abilities vary in whichsome of them have good English skills and others are still struggling to understand and speak English.

b. Many students do not speak English at home becausetheirparents cannot speak English well. Therefore, students merely speak English at school.

c. Students arelack of discipline during teaching and learning process, for instance lack of concentration and focus on the lesson taught, being sleepy and disruptive, chatting and playing with friends when teachers give explanation, and laziness to engage with the lesson.

d. Lack of vocabularies leads some 
students tends to keep silent, less talking in English, or even talking in Bahasa Indonesia.

e. Some students are lack of confidence when talking in English

f. Misspelling commonly occurs when they have to do some exercises or write some reports after conducting experiments.

g. Teachers find it difficultin creating students' habit to use English as daily language at school.

\section{Solutions}

From the problems occurred, teachers find several ways to overcome them. The following are the solutions they apply to make teaching and learning process run effectively,

a. Teachers provide a preparation class at the beginning of the semester for those who consider getting difficulty in using English to communicate. This preparation class will teach students daily vocabularies, speaking, reading, and writing.

b. Teachers give list of daily vocabularies for parents and hold regular meeting with them to discuss problems faced by students and the progress they make.

c. Achievement board is used to score students who always keep speaking English at school.

d. Punishment necklace (a small piece of paper written 'I will speak English more often' connected with string as necklace) is worn by students who speak Bahasa Indonesia in the classroom. The students will wear this necklace whole day.

e. Class Dojo Application is applied to control students' behavior and disciplines at school and also to monitor their progress and achievement in the classroom

f. During group work, teachers put students based on their English ability. Every group consists of mixed-abili- ty students.

g. English environment is set to provide students a place to practice their English and use it as daily language.

h. To avoid misunderstanding, teachers use simple sentences when explaining lesson or talking to students.

i. The program is full English. All the lesson, except Bahasa Indonesia, are taught by using English.

j. Teacher likes talking and speaking English in classroom. Besides, he always reminds students to speak English all the time.

k. Hands on learning is applied when teaching students to avoid boring atmosphere.

1. Teachers do not teach grammar to students. They will show how to speak correctly, show them corrected sentences and ask them to imitate or use them.

\section{Discussion}

The study was conducted to figure out problems in teaching English for young learners and reveal the solutions to overcome them. The result shows that there are 7 problems occurred and teachers offer 12 solutions to overcome those problems. In general, those problems can be categorized into 4, which are (1) students' discipline during teaching and learning process; (2) students' English ability; (3) support from parents; and (4) creating habit to implement English as daily language.

\section{(1) Students' discipline during teaching and learning process}

One of the challenges in teaching young learners is to keep them focus during the teaching and learning process. It is a nature of them that they are easier to get distraction. Young children have limited attention span; unless activities are extremely engaging, they can easily get bored, losing interest after ten minutes or so (Harmer, 2010) When the students feel bored, they will have tons of 
reasons such as feeling too exhausted, sleepy, difficult to understand the lesson, lazy to write, etc. They, therefore, tend to lose focus when teachers give explanation and prefer to have a chat or play with their friends. Short attention spans do come into play when the children have to deal with material that to them is boring, useless, or too difficult (Brown, 2001) It implies that to make them engaged and interested in teaching and learning process, teachers have to be more creative to bring the lesson alive and provide variety of activities. In addition, others key factors proposed by Brown (2001) to keep children focus are making them curious to materials or activities conducted in the classroom.

To encourage and keep students focus on the lesson, teachers implement achievement board, punishment necklace, Class Dojo Application, and hands-on-learning teaching methods.Before applying Class Dojo Application, teachers use achievement boards to give students appreciation when they always keep speaking English. Every student will compete to collect many stars. Teacher will update this board regularly. The more stars they get, the prouder they will be. Children learn abstract rules of language from which they listen, and even they also learn expressions that they have never heard before. It is extremely important that teachers not only get children to learn language, but they also encourage them to learn it positively (Hashemi and Azizinezhad, 2011)

However, the achievement board is no longer used at this school because it cannot be accessed by parents. Teachers, thus, implement Class Dojo Application to control students' behavior, discipline, and progress. This application enables parents and students themselves to access it. Every time students do the good things such as completing the task, helping others, keep speaking English, participating well during teaching and learning process, working hard, and cooperating in team work, teacher will score them one point. However, when they do something that are not allowed at schoolsuch as speaking Bahasa
Indonesia, bullying, playing with friends during the lesson, not doing the homework, etc., teachers will give them minus one. All students are very proud of Point Dojo that they are collected. They will feel regret when they get minus one, and on the contrary, they will be very happy if they get many points and become the top score. Besides, some students are afraid of their parents. They do not want their parents to be angry after knowing that they break the rule by checking from Class Dojo Application. Consequently, they will behave well and always try to keep talking in English. to get more plus point in Class Dojo Application. In other study conducted by Maclean-Blevins \&Muilenburg, (2013, cited in Robacker, Rivera, and Warren, 2016), Class Dojo has been shown to be successful in improving behavioral outcomes for students in elementary school classrooms.

Furthermore, Class Dojo Application is very easy to use and teachers are able to change some features of positive and negative points on application. Teacher can decide what rules that they are going to implement at school, thus, they will input them on Class Dojo Application.

Hands on learningis implemented as teaching methods. Most teachers tend not to use book or workbook during teaching and learning process. They believe that by implementing hands on learning, it will lead the students to think critically and creatively since they will combine between theories and practice or experiment. Children need handson activities to engage in their own learning. Concrete materials helps them understand and process the meaning (Uysal\&Yavuz, 2015).

Students' understanding comes not just from explanation, but also from what they see and hear and, crucially, have a chance to touch and interact with (Harmer, 2010) By implementing hands-on learning, students are able to study and do some experiment on what they just learnt. Furthermore, implementing hands on learning will decrease the possibility of getting bored during the lesson because during the learning process students are 
involved in certain activities in which they do not merely focus on the book. Fauziati (2010) argues when children are learning science or mathematics content they need to be actively involved in experimenting with mathematics or science materials that they can manipulate.

\section{(2) Students' English Abilities}

Having students who have different English ability in classroom is another problem faced by teachers. Moreover, English is used as daily language and all students have to speak English all time at school. When students do not have good English ability, they will be less confident and prefer to haveless communication with their friends or even keep silent.

Since not all students come from bilingual or international kindergarten, some of students have limited vocabularies, and they also get difficulty in spelling. In addition, they are reluctant to speak English and remain silent because they are afraid of getting punishment or minus one.

To overcome this problem, teachers have several solutions. First, they provide a preparation class for 3 months. This preparation class is for those who are struggling to catch up with their friends relating to English skills such as speaking, listening, reading, and writing. During the preparation class, students are taught daily vocabularies, speaking, reading and writing. Second, using achievement board. Besides to control students' behavior, achievement board aims to motivate students to always perform well during teaching and learning process. Teachers will give them stars whenever they perform well during the lesson. Third, to have student engage with the lesson and are able to practice speaking English, teachers make a group of student who consist of mixed - ability students. It aims to help the weak students be able to improve their English skills especially speaking skill. In addition, during the practice, students will always help one another. They will be happily help other students who are struggling with vocabularies.
Putting students in group gives more benefit for them to improve their confidence when speaking English.

Fourth, teachers use simple sentences when explaining and talking to students. They will choose simple dictions. In addition, when they have to use the new dictions in which many students are not familiar with, they will keep using it and repeating it during the lesson. According to Harmer (2010)repetition has always played a part in language learning, even if its efficiency in helping student to transfer knowledge from their short-term to long-term memories is not firmly established. Sixth, teachers avoid teaching grammar. Miss $\mathrm{T}$ considered that grammar should not be taught to young learners. The best time for them to learn grammar is at junior high school. Teachers just need to show them how to speak with grammatically correct without explaining grammar point and ask students to repeat or imitate it. Thus, it is in line with Brown's (2001) opinion. He states "Don't explain grammar using terms like "present progressive" or "relative clause". Furthermore, Harmer (2010) believes that young learners find abstract concepts such as grammar rules difficult to grasp. Young learners are basically able to learn grammar by using the language. Fromkinet.al (2007) highlight that no one teaches children the rules of grammar ... (children) are able to recreate the grammar of the language of their speech community based on the language they hear around them.

\section{(3) Creating Habit to Use English as Daily Language}

It is believed that language is a skill. The more you practice it. The better you will be. Therefore, creating English environment will help students to keep speaking English whole day, thus, it will be beneficial for them to improve their English skill, especially speaking.Fauziati (2010) states that teaching and learning process, therefore, should give enough opportunities to use English in 
everyday contexts. Children learn by doing; they learn language by using it (listening to it, speaking it, and writing it) (Palim\&Power citedin Fauziati, 2010) Unfortunately, inviting students to keep practicing their Englishspeaking skill is not an easy task. Teachers have to find the ways to make them speak English. One of the ways they implement at Al - Azhar 55 Islamic Primary School Yogyakarta is to keep reminding students to speak English. One of the teachers is very talkative. He likes speaking and inviting students to have conversation with him. Besides, he always keeps reminding students to speak in English and helps them whenever they get difficulty. However, this method works very well for students. By having the teacher like him, students are more confident to communicate in English. Brown (2001) suggests that (in teaching young learners) teachers should be patient and supportive to build self-esteem, yet at the same time be firm in your expectations of student. Miss T and Miss A agree that Mr. YI is very helpful, patient, and he always motivates students to speak English. Miss T states that "within six months, students' English skills grow very well ...it is because the program here is really reallyfull English ... Especially Mr. YI, he loves speaking English anyway, and he loves talking as well, ... so it's good combination". When the teacher is caring and helpful, however, students are much more likely to retain an interest in what's going on, and as a result, their self-esteem (an important ingredient in success) is likely to be nurtured (Harmer, 2007)

Miss $\mathrm{T}$ is a native teacher. She is able to speak Bahasa Indonesia well; however, she refuses to speakBahasaIndonesiawith students. Consequently, they are encouragedto practice speaking skill with her. As stated previously by Miss T., the program at this school is full English. All lessons are presented in English including Tilawah, reading Holi Qur'an. Ustad, teacher for reciting Holi Qur'an,speak English when giving explanation. Now, this school is able to create English environment for students. It implies that by providing
English environment, teachers are able to share their experiences when they learn language. Teachers, consequently, provide models of the language they are learning and share their knowledge of real -world task (Nunan, 1999)

\section{(4) Less Support from Parents}

When students are learning English, there are many factors that will help them to make learning process effective, one of them is the intensity of using English. Nunan (1999) states that learners are actively involved in using the language they are learning, and in learning through doing. It is considered that students should practice their English skill whenever they are, especially at home. Thus, parents' role to help students to practice their English is crucial. Harmer (2010) argues that learning (language) is 'assisted performance', and this happen when someone with more knowledge - say a parent or a teacher - helps the learner to progress. Unfortunately, not all parents are able to communicate in English.

To solve this problem, teachers provide teacher-parent meeting to discuss students' problems and progress. In this occasion, teacher will give parents list of daily vocabularies and some tips to help them speak English. Unfortunately, it significantly does not help them to be able to practice speaking English with their children at home. Nonetheless, to involve parents in helping students learning English,Class Dojo Application is implemented. What makes this application appealing is the ability to invite and incorporate teachers as well as parents to easily share student data and maintain communication (Robacker, Rivera, and Warren, 2016. By implementing Class Dojo Application, teachers invite parent to control students' progress, attitude at school, and the use of English. Parents are expected to actively access this application to monitor their children and communicate to teachers when their children get minus point. Krashen (cited in Yildirim\&Dogan, 2010) mentions that considering the characteristics young learners 
naturally bring when they are provided with the appropriate classroom atmosphere, young learners are ready to like the language, and their interest, by the help of maximized learning accelerates. It indicates that young learners need support and assistance during the learning process, especially to learn languages.

\section{Conclusion}

Teaching English for young learners can be very fun and interesting for teachers, however, there always challenges or problems occur during teaching and learning process. The present study investigates the problems occur at Al-Azhar 55 Islamic Primary School in Yogyakarta. In general, the problems occurred mostly from students and parents. Since the students have different backgrounds from the previous school, they have different ability in English skills which influences the learning process; besides, their lack of discipline during teaching and learning process makes English is difficult to be implemented as daily language. Meanwhile, less support from parents also influences the use of English as daily language since students are not able to speak English outside the classroom. Thus, implementing Class Dojo Application, Hands on Learning, and having supportive and encouraging teachers can be solutions to overcome the problems occurred.

\section{References}

Brown, H. Douglas. 2007. Teaching by Principles: An Interactive Approach to Language Pedagogy. New York: Pearson Education Inc.

Copland, Fiona, Garton, Sue, and Burns, Anne. 2013. "Challenges in Teaching English to Young Learners: Global Perspectives and Local Realities” Tesol Quarterly. vol. 48, No. 4

Creswell, John W. 2008. Educational Research: Planning, Conducting, and Evaluating Quantitative and Qualitative Research. New Jersey: Pearson Education Inc. Education Limited

Fauziati, Endang. 2010. Teaching English As A Foreign Language (TEFL). Surakarta: Era PustakaUtama.

Fromklin, Victoria, Rodman, Robert and Hyams, Nina. 2007. An Introduction to Language. Boston: Michael Rosenberg

Harmer, Jeremy. 2007. The Practice of English Language Teaching, fourth edition. Harlow: Pearson

Harmer, Jeremy. 2010. The Practice of English Language Teaching. Harlow, England: Pearson Longman

Hashemi, Masoud, and Azizinezhad, Masoud. 2011. "Teaching English To Children:A Unique ,Challenging Experience For Teachers, Effective Teaching Ideas”. Procedia - Social and Behavioral Sciences. Vol. 30, 2083 - 2087

$\mathrm{Hu}$, Y. (2007). China's foreign language policy on primary English education: What's behind it? Language Policy, vol. 6, 359-376.

Miles, M.B., \&Huberman,A.M. 1984. Qualitative Data Analysis. Thousand Oaks, CA: Sage.

Nunan, David, 1999, Second Language Teaching and Learning, Boston: Heinle\&Heinle Publisher

Robacker, Cassie M, Rivera, Christopher J. and Warren, Sandra H. 2016 "A Token Economy Made Easy Through ClassDojo" Intervention in School and Clinic. vol. 52(1), 39 -43 
Sayer, P. (2012). Ambiguities and tensions in English language teaching: Portraits of EFL teachers as legitimate speakers. New York: Routledge

Sen, Yusuf et al. 2014. Social benefits of an English learning program for young learners. Procedia - Social and Behavioral Sciences. Vol.152, 874 - 879.

Stakanova, Elena, and Tolstikina, Elena. 2014. Different Approaches to Teaching English as a Foreign Language to Young Learners". Procedia - Social and Behavioral Sciences. Vol. $146,456-460$

Stake, Robert E. 2010. Qualitative Research: Studying How Things Work. New York: The Guilford Press.

Strakova, Zuzan. 2015. "Challenges of Teaching English for Primary Level”. Procedia - Social and Behavioral Sciences. vol. 174, 2436 - 2443

Uysal, NuriyeDegirmenci, \&Favuz, Fatih. 2015. "Teaching English to Very Young Learners". Procedia - Social and Behavioral Sciences. Vol. 197, 19 - 22

Yıldırım, R. \&Doğan, Y. (2010). Young learner English teacher profile from students' perspective. Procedia Social and Behavioral Sciences. 2, 1615- 1619. 